\title{
DIVERSITY OF LEGUMINOUS Gliricidia sp. IN THAILAND AND UTILIZATION OF Gliricidia sepium AS A COMPOST FERTILIZER FOR SOIL IMPROVEMENT
}

\author{
SUVICHARK AROONLUK* \\ Program in Agricultural Science and Entrepreneurship, Faculty of Agriculture and Life Sciences, Chandrakasem Rajabhat \\ University, Bangkok, Thailand.
}

*Corresponding author: suvichark.a@gmail.com

Submitted final draft: 25 September 2020 Accepted: 4 October 2020

http://doi.org/10.46754/jssm.2021.08.012

\begin{abstract}
Research on plants in terms of their advantages or benefit characteristics is important and greatly contributes to scientific exploration into techniques for soil quality improvement. In this research, Gliricidia, an ornamental plant and exotic leguminous tree in Thailand, was used to study its property in soil improvement. This study aims to examine Gliricidia legume in 6 areas of Thailand and to determine the ability of the compost fertilizer produced with deciduous leaves from Gliricidia sepium in increasing soil fertility. Two species of legume ornamental tree can generally be found. The G. sepium, however, is more prevalent and common than G. maculata in the research area. Approach for isolation of G. sepium from G. maculata was based on botanical taxonomy, and the evaluation of specific tissues of pendulous inflorescence and calyx tissue was carried out in the experiment. It was found that compost fertilizer produced with $G$. sepium deciduous leaf greatly induced the growth of tested sweet corn and soil nutrient quality. In addition, the supplementation of $20 \%$ concentration, followed by $5 \%$ and $10 \%$, respectively, effectively promoted the growth of tested sweet corn and substantially increased soil fertility. Data from this research can be further applied to work towards comprehensive solutions for restoration of soil organic matter throughout organic farming and repetitive harvesting of crops.
\end{abstract}

Keywords: Gliricidia, Gliricidia sepium, Gliricidia maculata, compost fertilizer, soil fertility improvement.

\section{Introduction}

Plant resources are crucial for ecologically complex systems and provide valuable benefits to humankind. However, the increasing population of humans and climate change is currently leading to rapid decline and loss of plant resources in nature. The development of suitable conservation strategies is important for proper utilization and sustainability of plant resources (Howard et al., 2008; Tandon et al., 2012). With regard to plant resources in Thailand, six biogeographical units and five types of forest resources can be classified into groups, including various kinds of agricultural resources and plant species. About 80 percent of at least 10,000 forest trees and medicinal plants can be used for various alternative features including medication, agroforestry and agriculture (Thitiprasert et al., 2007; Woodruff,
2010). Agricultural activity plays a significant role in production of food, food ingredients, as well as fertilizers derived from plant resources. Moreover, Thailand plant genetic resources (PGR) report indicates that conservation and utilization of important economic crops, including rice, maize, soybean and sugarcane result in substantial rise in the value of leguminous tree, Gliricidia sp. Gliricidia is a genus of flowering plants in the legume family that belongs to the subfamily Faboideae and tribe Robinieae (Mcneill et al., 2006; Lavin \& Sousa, 1995). Gliricidia is basically classified into three species based on plant taxonomy: Gliricidia brenningii (Harms) Lavin., Gliricidia maculata (H.B.K.) Steud. and Gliricidia sepium (Jacq) Steud. These three species are native in Mexico and Central America. Gliricidia, leguminous, is a multifunction tree and able to grow in a number 
of different climates and eroded soil (Stewart et al., 1996; Lavin et al., 1991). Gliricidia, leguminous grows rapidly after pruning and deciduosity. It also has nitrogen fixation ability for soil fertility improvement and is employed in intercropping with cocoa plantation. The Gliricidia, leguminous is also referred to as "Mother of cocoa" because of its outstanding advantages in soil improvement. G. sepium was later introduced to other countries, including India, Sri Lanka, Philippine and Thailand (Stewart et al., 1996; Maundu \& Tengnäs, 2005; Batish et al., 2007). In Thailand, $G$. sepium is called 'khae farang', and used as fuel wood, living fences, green manure, fodder and medicine (Stewart \& Simons, 1995; Tantengco \& Jacinto, 2015). Green manure derived from khae farang or G. sepium is used as fertilizer to increase nitrogen uptake more effectively in corn than in corn stubble (Bah \& Rahman, 2001). Moreover, G. sepium intercropping was used to improve soil properties and corn yield in South Africa (Beedy et al., 2010). In spite of extensive use in Thailand, the difference between $G$. maculata and G. sepium in terms of taxonomy character is still unclear, and legume trees have not been utilized in agriculture development. This research aims to examine the diversity of Gliricidia leguminous tree in six areas of Thailand and perform pot trial determination of G. sepium, and compost fertilizer in long-term agricultural practice soil samples from Chai Nat province, Thailand.

\section{Materials and Methods}

\section{Diversity Observation of Gliricidia leguminous Tree in Thailand}

Samples of Gliricidia leguminous trees were obtained from parks and a national park in six biogeographical units of Thailand by using the purposive selection sampling method (Table 1). The botanical taxonomy of each Gliricidia $s p$. was characterized using the method specified by Stewart et al., (1996). Taxonomic species of all plant samples were scrutinized and classified based on morphology of leaves, pendulous inflorescence, calyx, staminal tube and pod
(Stewart et al., 1996).

Preparation of Soil sampling and G. sepium organic compost fertilizer

Soil sample was collected in an area of Tambon makamtao, Wat Sing district, Chai Nat province at latitude 15.21456831 and longitude 100.02268497. The coordinate location of soil series number 7 was obtained from Thailand geographical soil database from LDD Soil Guide Mobile and Agri-Map Mobile application provided by Land Development Department and National Electronic and Computer Technology Center (NECTEC) (Land Development Department, 2016; National Electronics and Computer Technology Center (NECTEC), 2017). Soil sampling was performed with technique described by Carter and Gregorich, (2007), and soil was collected, air dried and crushed by crucible grinder. The soil sample was subsequently kept in dry condition at room temperature until use. Deciduous leaves on the G. sepium were harvested at Chandrakasem Rajabhat University, Bangkok campus. All of the leaves were further composted for 2 weeks using modified organic composting procedure according to the rapid composting recommendation (Raabe, 1981; Food and Agriculture Organization of the United Nations (FAO), 2010). The organic leaves compost produced was dark brown in color and crumbly in texture. The compost was further crushed and sieved using a $11.2 \mathrm{~mm}$ mesh. The compost fertilizer was later kept in dry condition at room temperature until use.

\section{Efficiency Measurement of Different Compost Fertilizer Concentration in Supplemented Soil Samples for Induction of Plant Growth}

The pot trial was designed by using completely randomized design (CRD) under greenhouse conditions. The percentage of soil organic matter (SOM) ranged from 1 to 6 percent (Troeh \& Thompson, 2005), which was used to calculate and modify the concentration of the G. sepium compost fertilizer in the soil sample. There were, accordingly, 4 treatments: (1) $100 \%$ soil sample without G. sepium compost fertilizer, 
(2) $6.65 \mathrm{~kg}$ of soil containing $5 \%(0.35 \mathrm{~kg})$ of G. sepium compost fertilizer, (3) $6.3 \mathrm{~kg}$ of soil containing $10 \%(0.7 \mathrm{~kg})$ of G. sepium compost fertilizer and (4) $5.6 \mathrm{~kg}$ of soil containing $20 \%$ $(1.4 \mathrm{~kg})$ of G. sepium compost fertilizer. Sweet corn (Supersweet corn ${ }^{\circledR}$, Chua yong seng seed co., LTD) was used as a test plant to determine the efficiency of compost fertilizer that induces plant growth and development. Sweet corn at 1 week after emerging was transplanted into each treatment. The transplanting preparation was made by loading $7 \mathrm{~kg}$ of planting material treatments into pots. The pots were covered with rice straw, and also irrigated every day with 500 $\mathrm{ml}$ of water per pot. The growing plant was evaluated in respect of vegetative growth rate by determination of plant height, stem diameter, leaf area and leaf number during the $4^{\text {th }}$ and $8^{\text {th }}$ week after transplantation. Plant height was measured from the base to the last node of corn. Stem diameter was measured at the center of plant height (Nleya et al., 2016). Leaf area was obtained by the equation: leaf area (LA) $=0.75 \mathrm{X}$ Leaf length $(\mathrm{cm}) \mathrm{X}$ Leaf width $(\mathrm{cm})$ (Maddonni \& Otegui, 1996).

\section{Evaluation of Compost Fertilizer Supplementation for Changing of Soil Nutrition}

Soil sample was supplemented with compost fertilizer and 3 replication of each of the 4 treatments. The 4 treatments consisted of (1) $100 \%$ soil sample without G. sepium organic compost fertilizer as a control, (2) Soil sample containing $5 \%$ G. sepium organic compost fertilizer, (3) Soil sample containing 10\% G. sepium organic compost fertilizer and (4) Soil sample containing $20 \%$ G. sepium organic compost fertilizer. Soil supplementation from each treatment was covered with rice straw, watered once a week and maintained in greenhouse condition for 8 weeks. Each replication of soil sample was pooled, air dried and grounded in a soil mill at room temperature and indoor condition. In each treatment, the soil nutrient composition was analysed from pooled soil samples. The $\mathrm{pH}$, electrical conductivity
(EC), total nitrogen $(\mathrm{N})$, organic matter $(\mathrm{OM})$, potassium $(\mathrm{K})$, phosphorus $(\mathrm{P})$ and calcium $(\mathrm{Ca})$ were subsequently measured. The analysis and measurement were conducted by the office of Agricultural Research and Development Region 5, Chai Nat province, Thailand.

\section{Statistical Data Analysis}

Analysis and measurement of significant variances from different treatments were carried out using plant growth factors and one way ANOVA, Duncan Multiple Range Test (DMRT) with t-test $(\mathrm{p}<0.05)$.

\section{Results and Discussion}

\section{Diversity of Gliricidia sp. Distribution in Thailand}

Genus Gliricidia comprises three species: Gliricidia brenningii (Harms) Lavin., Gliricidia maculata (H.B.K.) Steud. and Gliricidia sepium (Jacq) Steud. (Lavin et al., 1991; Stewart et al., 1996). G. sepium is the most widely known and has spread beyond its native range. G. brenningii has more differences from $G$. maculata and $G$. sepium, whereas G. Maculata and G. sepium share many similarities and differences between the two species remain obscure (Stewart et al., 1996). Only G. maculata and G. sepium can be found in these areas of Thailand (Table 1). Additionally, G. sepium was mostly found in 5 geographical units in Thailand except in the southern area. G. sepium was also discovered in 478 samples from all observation area units, whereas G. maculata was observed in only 71 samples from the same area (Table 1).

G. sepium is more extensively used as an ornamental plant than G. maculata. However, there is still confusion about taxonomic classification of the two species. In order to differentiate G. maculata from G. sepium, a technique relying on leguminous Gliricidia and botanical features of specific parts of the two species was employed (Lavin et al., 1991; Stewart et al., 1996). The botanical features are the leaves, pendulous inflorescences, calyx, staminal tubes and pods, as shown in 
Table 1: Observation of leguminous Gliricidia sp. in different biogeographical units of Thailand

\begin{tabular}{|c|c|c|c|c|c|}
\hline \multirow{2}{*}{$\begin{array}{c}\text { Biogeographical units of } \\
\text { Thailand }\end{array}$} & \multirow[t]{2}{*}{ Observation area } & \multicolumn{4}{|c|}{ Present status of leguminous Gliricidia sp. } \\
\hline & & G. brenningii & G. maculata & G. sepium & Total \\
\hline $\begin{array}{l}\text { 1. Northern area } \\
\text { - Chiangmai province }\end{array}$ & $\begin{array}{c}\text { Park } \\
\left(0.0083 \mathrm{~km}^{2}\right)\end{array}$ & - & 8 & 35 & 43 \\
\hline $\begin{array}{l}\text { 2. Northeastern area } \\
\text { - Khon kaen province }\end{array}$ & $\begin{array}{c}\text { Park } \\
\left(0.0164 \mathrm{~km}^{2}\right)\end{array}$ & - & 14 & 10 & 24 \\
\hline $\begin{array}{l}\text { 3. Central area } \\
\text { - Bangkok }\end{array}$ & $\begin{array}{c}\text { Park } \\
\left(0.0164 \mathrm{~km}^{2}\right)\end{array}$ & - & 15 & $\begin{array}{l}86 \\
50\end{array}$ & $\begin{array}{c}101 \\
50\end{array}$ \\
\hline - Pathum thani province & $\begin{array}{c}\text { Park } \\
\left(0.0136 \mathrm{~km}^{2}\right)\end{array}$ & - & $\overline{1}$ & 60 & $\begin{array}{l}50 \\
61\end{array}$ \\
\hline $\begin{array}{l}\text { - Chandrakasem Rajabhat } \\
\text { University, Bangkok } \\
\text { campus }\end{array}$ & $\begin{array}{c}\text { Park } \\
\left(0.024 \mathrm{~km}^{2}\right)\end{array}$ & - & - & 40 & 40 \\
\hline $\begin{array}{l}\text { - Chandrakasem Rajabhat } \\
\text { University, Chai Nat } \\
\text { campus }\end{array}$ & $\begin{array}{c}\text { Park } \\
\left(0.024 \mathrm{~km}^{2}\right)\end{array}$ & & & & \\
\hline $\begin{array}{l}\text { 4. Eastern area } \\
\text { - Prachinburi province }\end{array}$ & $\begin{array}{c}\text { Park } \\
\left(0.0256 \mathrm{~km}^{2}\right)\end{array}$ & - & 7 & 95 & 102 \\
\hline $\begin{array}{l}\text { 5. Western area } \\
\text { - Ratchaburi province }\end{array}$ & $\begin{array}{l}\text { National Park } \\
\left(0.032 \mathrm{~km}^{2}\right)\end{array}$ & - & 20 & 102 & 122 \\
\hline $\begin{array}{l}\text { 6. Southern area } \\
\text { - Nakhon Si Thammarat } \\
\text { Province }\end{array}$ & $\begin{array}{c}\text { Park } \\
\left(0.0096 \mathrm{~km}^{2}\right)\end{array}$ & - & 6 & 0 & 6 \\
\hline Total & & $\mathbf{0}$ & 71 & 478 & 549 \\
\hline
\end{tabular}

Figure 1. It was found that leaf samples from G. sepium showed broadly oblong shape, leaflets and alternate pinnate leaves. The leaf samples from G. maculata, on the other hand, showed distinctive pointed apices, leaflets, and alternate pinnate leaves (Figure 1a-b). As for the pendulous inflorescence, a significant difference in color was seen. G. sepium has pink flowers, whereas G. maculata has white flowers in the pendulous inflorescences (Figure 1c-d). $G$. sepium calyx was bright green mixed with pink, while G. maculata calyx was yellowish green (Figure 1e-f). Staminal tube of G. sepium was purple, whereas it was yellowish white in $G$. maculata (Figure 1g-h). Pod of G. sepium was long and greenish, whereas it was narrow and yellowish green in G. maculata (Figure 1i-j). The findings were highly correlated with results from previous studies (Lavin et al., 1991; Stewart et al., 1996) except that the results from this study suggested that the calyx and staminal tube from both G. maculata and G. sepium showed clear color.

In this research, the outcomes indicated that G. sepium is the most commonly found species throughout the research area. Therefore, $G$. sepium was selected as a compost fertilizer, and the optimum percent concentration of G. sepium for induction of plant growth was investigated. 
(a)

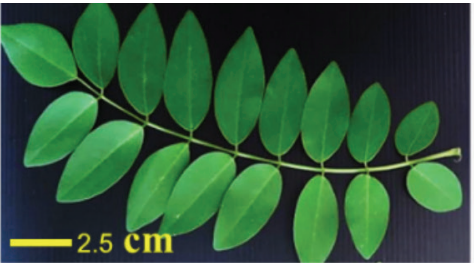

(c)

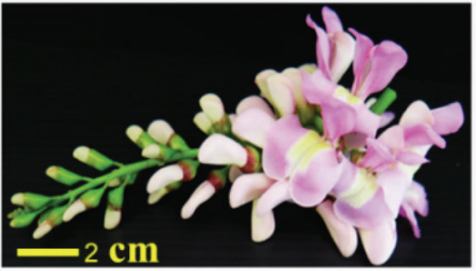

(e)

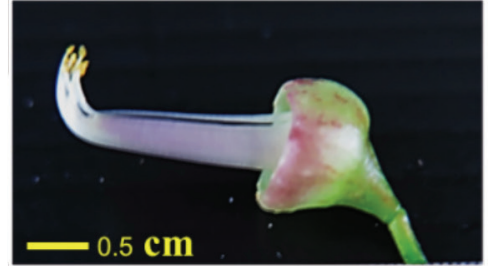

(g)

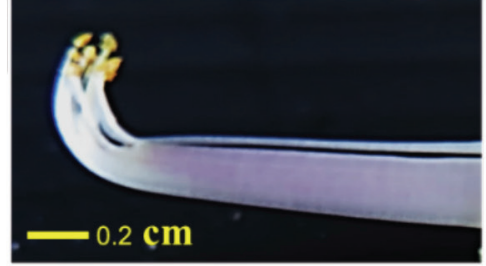

(i)

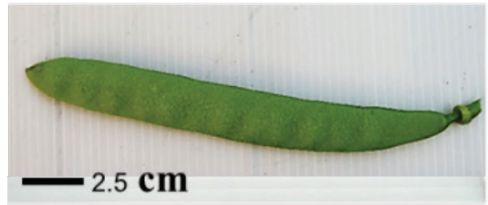

(b)

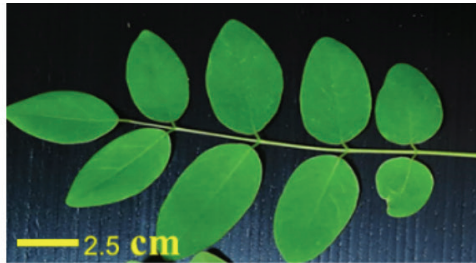

(d)

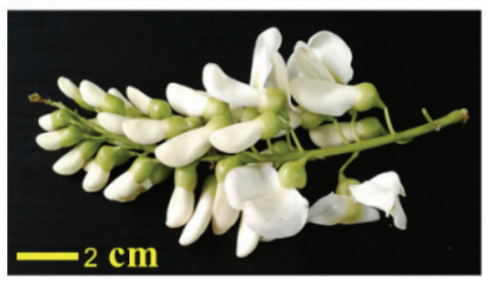

(f)

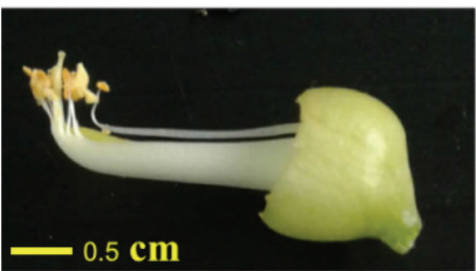

(h)

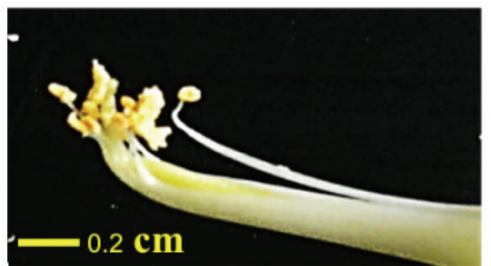

(j)

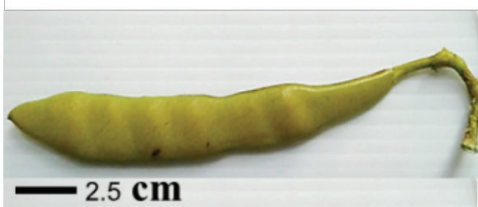

Figure 1: Botanical features of specific parts showed differences between the two leguminous trees: Gliricidia sepium and Gliricidia maculata; a: leaves (G. sepium), b: leaves (G. maculata), c: pendulous inflorescence

(G. sepium), d: pendulous inflorescence (G. maculata), e: calyx (G. sepium), f: calyx (G. maculata), g: staminal tube (G. sepium), h: staminal tube (G. maculata), i: pod (G. sepium), j: pod (G. maculata)

The Measurement of G. sepium Compost Fertilizer Promoting Plant Growth and Development

The efficacy evaluation of G. sepium compost fertilizer to induce sweet corn growth and development was made at vegetative stage (V8$\mathrm{V} 9$ and V16-V17). The tested plants and growth parameters are shown in Figure 2 and Table 2. Growth rate and phenotypes of sweet corn, as a tested plant, were evaluated. The results indicated that sweet corn cultivated with soil supplemented with G. sepium fertilizer showed growth and development rate higher than that of the control (Figure 2). The growth parameters were evaluated at 4 weeks after transplantation (V8-V9 stage). When $10 \%$ G. sepium fertilizer was used, it found that height and leaf number of the sweet corn were $25.75 \pm 0.29 \mathrm{~cm}$ and $7.25 \pm 0.50 \mathrm{~cm}$, respectively, which were significantly higher than that of the control (Table 2). The largest stem size and leaf area were obtained when treated with $20 \%$ fertilizer. As for the growth rate at 8 weeks after transplantation 
(V16-V17), the maximum height and largest leaf number were gained when cultivation was done with soil supplemented by $5 \%$ fertilizer
(Table 2). The highest development of stem size and leaf area was observed when treated with $20 \%$ percent supplementation (Table 2 ).
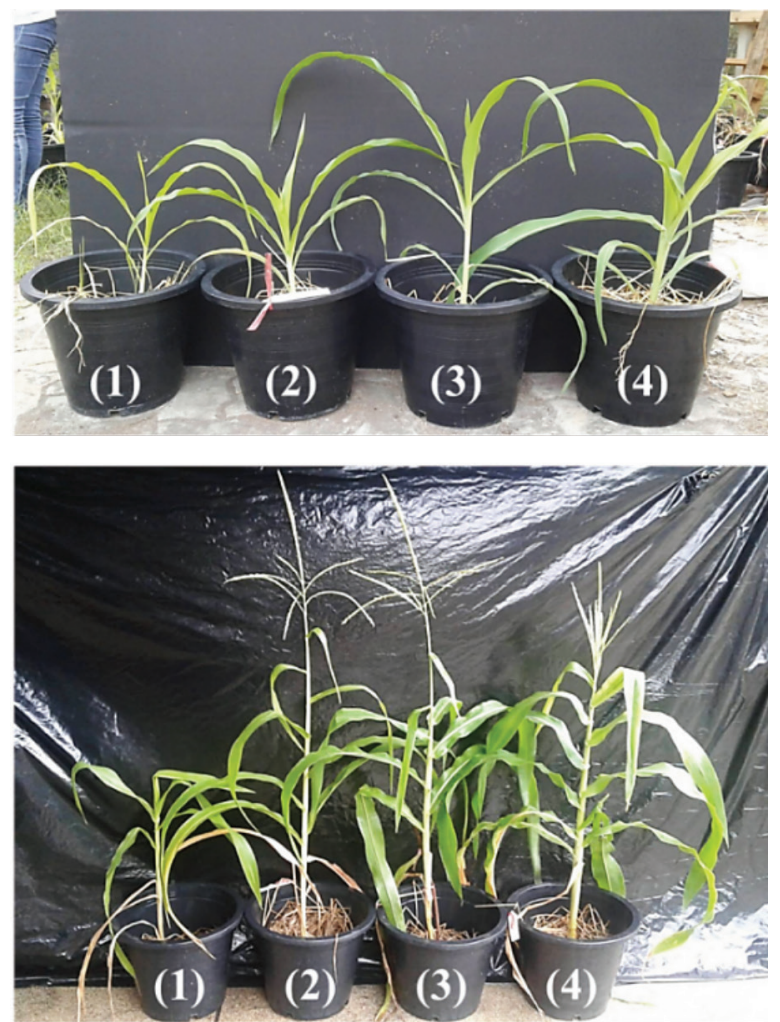

Figure2: Measurement of plant growth in various treatments of G. sepium compost fertilizer. a; Sweet corn at 4 weeks after transplantation, b; Sweet corn at 8 weeks after plantation, (1); soil sample without G. sepium compost fertilizer, (2); soil sample with 5\% G. sepium compost fertilizer, (3); soil sample with $10 \%$ G. sepium compost fertilizer, (4); soil sample with $20 \%$ G. sepium compost fertilizer.

Table 2: Growth rate of sweet corn in various treatments of G. sepium compost fertilizer

\begin{tabular}{lcccc}
\hline \multicolumn{1}{c}{ Treatment } & $\begin{array}{c}\text { Plant height } \\
(\mathbf{c m})\end{array}$ & $\begin{array}{c}\text { Stem size } \\
(\mathbf{c m})\end{array}$ & $\begin{array}{c}\text { Leaf area } \\
(\mathbf{L A})\end{array}$ & $\begin{array}{c}\text { Leaf number } \\
\text { (leaves/plant) }\end{array}$ \\
\hline 4 weeks after transplantation & & & & \\
\hline Control & $13.34 \pm 0.69^{\mathrm{a}}$ & $2.06 \pm 0.44^{\mathrm{a}}$ & $58.94 \pm 5.75^{\mathrm{a}}$ & $4.60 \pm 0.55^{\mathrm{a}}$ \\
$5 \%$ G. sepium compost fertilizer & $20.78 \pm 0.93^{\mathrm{b}}$ & $2.65 \pm 0.24^{\mathrm{b}}$ & $144.39 \pm 4.57^{\mathrm{b}}$ & $7.50 \pm 0.58^{\mathrm{b}}$ \\
$10 \%$ G. sepium compost fertilizer & $25.75 \pm 0.29^{\mathrm{c}}$ & $2.63 \pm 0.30^{\mathrm{b}}$ & $159.97 \pm 8.66^{\mathrm{c}}$ & $7.25 \pm 0.50^{\mathrm{b}}$ \\
$20 \%$ G. sepium compost fertilizer & $22.75 \pm 0.61^{\mathrm{d}}$ & $3.08 \pm 0.46^{\mathrm{b}}$ & $186.04 \pm 2.42^{\mathrm{d}}$ & $7.00 \pm 0.82^{\mathrm{b}}$ \\
F-test & 276.98 & 5.56 & 53.03 & 22.14 \\
CV $(\%)$ & 3.35 & 14.61 & 12.01 & 9.53 \\
\hline
\end{tabular}


8 weeks after transplantation

\begin{tabular}{ccccc}
\hline Control & $31.18 \pm 1.16^{\mathrm{a}}$ & $2.41 \pm 0.02^{\mathrm{a}}$ & $120.33 \pm 7.72^{\mathrm{a}}$ & $7.00 \pm 1.41^{\mathrm{a}}$ \\
$5 \%$ G. sepium compost fertilizer & $73.53 \pm 0.92^{\mathrm{b}}$ & $3.38 \pm 0.15^{\mathrm{b}}$ & $258.49 \pm 5.50^{\mathrm{b}}$ & $10.25 \pm 0.50^{\mathrm{b}}$ \\
$10 \%$ G. sepium compost fertilizer & $65.15 \pm 0.58^{\mathrm{c}}$ & $3.40 \pm 0.25^{\mathrm{b}}$ & $230.34 \pm 9.91^{\mathrm{b}}$ & $9.50 \pm 0.58^{\mathrm{b}}$ \\
$20 \%$ G. sepium compost fertilizer & $67.75 \pm 1.23^{\mathrm{d}}$ & $4.38 \pm 0.15^{\mathrm{c}}$ & $398.32 \pm 6.85^{\mathrm{c}}$ & $10.25 \pm 0.50^{\mathrm{b}}$ \\
F-test & 1,680 & 13.73 & 48.11 & 117.47 \\
CV $(\%)$ & 1.17 & 6.77 & 5.11 & 11.26 \\
\hline
\end{tabular}

The Measurement of the efficiency of $G$. sepium fertilizer supplementation in the soil sample was carried out in this experiment (Table 2). G. sepium fertilizer can induce the growth and development during vegetative stage of corn from V1 to V12. The sweet corn from V1 to V12 stages required considerable amount of macronutrients, especially potassium, nitrogen and phosphorus, As a consequence, the efficacy of $G$. sepium fertilizer supplementation was determined during these stages (Ritchie et al., 1997; Bender et al., 2013). The results indicated that each different percentage content of $G$. sepium fertilizer has a positive effect on plant growth at various levels. Induction of plant growth at 4 weeks after transplantation occurred when the fertilizer was utilized at the amount of $10 \%$ and $20 \%$. However, the effective response of sweet corn to the fertilizer at the amount of $5 \%$ and $20 \%$ was observed after 8 weeks of transplantation. These results closely correspond to previous studies suggesting that G. sepium demonstrated its ability to recruit and release nutrients to induce the growth of Hypsipyla grandella in a Cedrelaodorata plantation (Montero-Solís et al., 2019). In addition, pruning of $G$. sepium efficiently increased growth rate and yield of cowpea (Vigna unguiculata Walps) and also raised the soil nutrient content that brought about an improvement in soil fertility (Awodun et al., 2007). Moreover, G. sepium was reported to be utilized as an alternative to chemical fertilizers and pesticidal properties of $G$. sepium were observed in rice fields in Southern Luzon, Philippines (Villegas-Pangga, 2010).

\section{Efficacy of G. sepium Compost Fertilizer to Improve Soil Fertility}

The information on subject soil series number 7 was obtained from LDD Soil Guide Mobile and Agri-Map Mobile application provided by the Land Development Department and National Electronic and Computer Technology Center (NECTEC). Data derived from the applications showed 6.0-7.0 range of $\mathrm{pH}$, and moderate abundance of chemical elements were detected in the soil sample. Top soil consisted of 3.8\% organic matter, $2.6 \mathrm{mg} / \mathrm{kg}$ of phosphorus and $89.2 \mathrm{mg} / \mathrm{kg}$ of potassium (Land Development Department, 2016; National Electronics and Computer Technology Center (NECTEC), 2017). To evaluate soil chemical compositions from different treatments with $G$. sepium compost fertilization, the soil sample from each of the treatments was collected at 8 weeks after fertilizer induction. The chemical properties of soil supplemented with $5 \%, 10 \%$ and $20 \% G$. sepium fertilizer is shown in table 3 . There is a trend of $\mathrm{pH}$ and electrical conductivity (EC) of soil to increase with higher percentage of the organic compost fertilizer concentration (Ozlu $\&$ Kumar, 2018). There was an increase in the amount of total nitrogen $(\mathrm{N})$, organic matter $(\mathrm{OM})$, and calcium $(\mathrm{Ca})$ when the soil samples were supplemented with high concentration of G. sepium compost fertilizer. It was previously reported that calcium accounted for 1.3 percent of G. sepium dry matter (Speedy, 2004). Therefore, the increasing concentration of $G$. sepium compost fertilizer resulted in the rising amount of calcium in each treatment. However, the chemical content of potassium 
(K) and phosphorus (P) decreased with 20\% G. sepium fertilizer supplementation, which was possibly influenced by leaching during the maintenance of soil moisture. Soil sample tests revealed that a high nutritional content was correlated directly to the utilization of $G$. sepium fertilizer. The previous result showed G. sepium leguminous tree was capable of improving soil nutrients, enhancing soil quality, preventing soil degradation, and hindering soil structure alteration (Montero-Solís et al., 2019). The result closely corresponded with previous studies on cowpea (Awodun et al., 2007) and rice field (Villegas-Pangga, 2010). These results suggested that the utilization of $G$. sepium compost could convert soil nitrogen $(\mathrm{N})$ to nitrate, which was the most available form of nitrogen at 80 days after decaying in soil. Moreover, corn was able to absorb available nutrients from $G$. sepium green manure in an amount higher than corn stubble (Bah \& Rahman, 2001).

\section{Conclusion}

The genus Gliricidia, native to Mexico and Central America, comprises three species: Gliricidia brenningii, Gliricidia maculata and Gliricidia sepium. G. sepium is mostly found in five areas of Thailand and differentiated from G. maculata by taxonomic classification based on botanical features of pendulous inflorescence and calyx tissue. G. sepium deciduous leaf can be collected to produce compost using a simple method, and it was further used as a natural organic compost fertilizer for improving soil fertility. The compost fertilizer containing 20\% and $10 \%$ G. sepium improved soil fertility the most. The leguminous compost fertilizer greatly induced sweet corn growth and development during vegetative stages. G. sepium is a multifunctional plant and easy to propagate by cuttings. The fertilizer from composted G. sepium can also reduce economic costs more effectively when compared to chemical fertilizers. The study of Gliricidia in terms of physical and chemical aspects and its properties as a component of a compost fertilizer in this research will provide insights into soil quality improvement in repetitive agriculture and organic farming.

\section{Acknowledgements}

This research was supported by the 2016 fiscal year budget of Chandrakasem Rajabhat University and Institute of Research and Development, Chandrakasem Rajabhat University.

Table 3: Physical and chemical properties of soil in various treatments of $G$. sepium compost fertilizer at 8 weeks after induction

\begin{tabular}{|c|c|c|c|c|c|c|c|}
\hline Treatment & pH & $\begin{array}{c}\mathrm{EC} \\
(\mathrm{mS} / \mathrm{cm})\end{array}$ & $\begin{array}{c}\text { Total N } \\
(\%)\end{array}$ & $\begin{array}{l}\text { OM } \\
(\%)\end{array}$ & $\begin{array}{c}\mathrm{K} \\
(\mathrm{ppm})\end{array}$ & $\begin{array}{c}\mathrm{P} \\
(\mathrm{ppm})\end{array}$ & $\begin{array}{c}\mathrm{Ca} \\
(\mathrm{ppm})\end{array}$ \\
\hline Control & $5.90 \pm 0.021^{\mathrm{d}}$ & $0.04 \pm 0.002^{\mathrm{d}}$ & $0.054 \pm 0.002^{\mathrm{d}}$ & $1.09 \pm 0.014^{\mathrm{d}}$ & $35.89 \pm 0.782^{b}$ & $30.22 \pm 0.667^{d}$ & $365.33 \pm 0.014^{\mathrm{d}}$ \\
\hline $\begin{array}{l}5 \% \text { G. } \\
\text { sepium } \\
\text { compost } \\
\text { fertilizer }\end{array}$ & $6.88 \pm 0.027^{\mathrm{c}}$ & $0.08 \pm 0.001^{\mathrm{c}}$ & $0.081 \pm 0.001^{\mathrm{c}}$ & $1.66 \pm 0.013^{\mathrm{c}}$ & $22.44 \pm 1.014^{\mathrm{c}}$ & $67.22 \pm 0.883^{\mathrm{c}}$ & $604.33 \pm 1.118^{c}$ \\
\hline $\begin{array}{l}10 \% G \text {. } \\
\text { sepium } \\
\text { compost } \\
\text { fertilizer }\end{array}$ & $6.97 \pm 0.019^{\mathrm{b}}$ & $0.14 \pm 0.001^{\mathrm{b}}$ & $0.119 \pm 0.001^{\mathrm{b}}$ & $1.93 \pm 0.008^{\mathrm{b}}$ & $46.89 \pm 1.167^{\mathrm{a}}$ & $92.56 \pm 0.882^{\mathrm{a}}$ & $1041.44 \pm 0.527^{b}$ \\
\hline $\begin{array}{l}20 \% G \text {. } \\
\text { sepium } \\
\text { compost } \\
\text { fertilizer }\end{array}$ & $7.38 \pm 0.014^{\mathrm{a}}$ & $0.19 \pm 0.002^{\mathrm{a}}$ & $0.123 \pm 0.001^{\mathrm{a}}$ & $2.12 \pm 0.010^{\mathrm{a}}$ & $20.33 \pm 0.866^{\mathrm{d}}$ & $85.78 \pm 0.972^{\mathrm{b}}$ & $1,389.89 \pm 4.014^{a}$ \\
\hline
\end{tabular}




\section{References}

Awodun, M. A., Odogiyan, A., \& Ojeniyi, S. O. (2007). Effect of Gliricidia pruning on soil and plant nutrient status and yield of cowpea. International Journal of Agricultural Research, 2, 402-405.

Bah, A. R., \& Rahman, Z. A. (2001). Gliricidia (Gliricidia sepium) green manures as a potential source of $\mathrm{N}$ for maize production in the tropics. Scientific World Journal, 22(1), 90-95.

Batish, D. R., Kohli, R. K., Jose, S., \& Singh, H. P. (2007). Ecological basis of agroforestry. LLC, USA: Taylor \& Francis Group. 382 pp.

Beedy, T. L., Snapp, S. S., Akinnifesi, F. K., \& Sileshi, G. W. (2010). Impact of Gliricidia sepium intercropping on soil organic matter fractions in a maize-based cropping system. Agriculture, Ecosystems and Environment, 138(3-4), 139-146.

Bender, R. R., Haegele, J. W., Ruffo, M. L., \& Below, F. E. (2013). Modern corn hybrids' nutrient uptake patterns. Better Crops, 97(1), 7-10.

Carter, M. R., \& Gregorich, E. G. (2007). Soil sampling and methods of analysis ( $\left.2^{\text {nd }} \mathrm{ed}.\right)$. Boca Raton. Canada: Canadian Society of Soil Science, Taylor \& Francis Group, LLC. 1264 pp.

Food and Agriculture Organization of the United Nations (FAO). (2010). Preparation and use of compost. Technologies and Practices for Small Agricultural Producers, 1-12.

Howard, P., Puri, R., Smith, L., \& Altierri, M. (2008). A scientific conceptual framework and strategic principles for the globally important agricultural heritage systems programme from a social-ecological systems perspective. Rome: Food and Agriculture Organization of the United Nations, USA. 144 pp.

Land Development Department. (2016). LDD Soil Guide(Version 1.4.0). App store, https://apps.apple.com/th/app/ldd-soilguide/id1072018597

Lavin, M., Mathew, S., \& Hughes, C. (1991). Chloroplast DNA variation in Glicidia sepium (Leguminosea): Interspecific phylogeny and togogeny. American Journal of Botanica, 78(11), 1576-158.

Lavin, M., \& Sousa, M. (1995). Phylogenetic systematic and biogeography of the tribe Robinieae(Leguminosae). Systematic Botany Monographs, 45, 1-160.

Maddonni, G. A.,\& Otegui, M. E. (1996). Leaf area, light interception, and crop development in maize. Field Crops Research, 48, 81-87.

Maundu, P., \& Tengnäs, B. (2005). Useful trees and shrubs for Kenya.World Agroforestry Centre-Eastern and Central Africa Regional Programme (ICRAF-ECA), Kenya. 484 pp.

Mcneill, J., Barrie, F. R., Burdet, H. M., Demoulin, V., Hawksworth, D. L., \& et al. (eds.) (2006). International code of botanical nomenclature (Vienna Code). Adopted by the Seventeenth International Botanical Congress Vienna, Austria, July 2005. Regnum Vegetabile, 146, 1-568.

Montero-Solís, F. M., López-López, M. Á., Jiménez-Casas, M., Cetina-Alcalá, V. M., Platas-Rosado, D. E., \& López-Collado, C. J. (2019). Gliricidia sepium and fertilization affect growth, nutrientstatus, and incidence of Hypsipyla grandella in a Cedrelaodorata plantation. Agroforest System, 93, 813-823.

National Electronics and Computer Technology Center (NECTEC). (2017). Agri-Map Mobile(Version 1.5.40). App store, https:// apps.apple.com/th/app/agri-map-mobile/ id1231363012? $=$ th

Nleya, T., Chungu, C., \& Kleinjan, J. (2016). Corn growth and development. iGrowCorn: Best Management Practices, 5-8.

Ozlu, E., \& Kumar, S. (2018). Response of soil organic carbon, $\mathrm{pH}$, electrical conductivity, and water stable aggregates to long-term 
annual manure and inorganic fertilizer. Soil Science Society of America Journal, 82, 1243-1251.

Raabe, R. D. (1981). The rapid composting method. Berkeley, USA: University of California.

Ritchie, S. W., Hanway, J. J., \& Benson, G. O. (1997). How a corn plant develops. Special report No. 48. Ames, Iowa. USA: Iowa State University Press. 24 pp.

Speedy, A. (2004). Gliricidia sepium. Tropical Feeds and Feeding Systems, 253-2.

Stewart, J. L., Allison, G. E., \& Simons, A. J. (1996). Glicidia sepium: Genetic resources for farmers. Tropical forestry papers No.33. Oxford Forestry Institute, Department of Plant Sciences, University of Oxford, UK. $125 \mathrm{pp}$.

Stewart, J. L., \& Simons, A. J., (1995). Opportunities and limitations in Gliricidia. In Shelton, H. M., Piggin, C. M., Brewbaker, J. L. (Eds.), Limitations and opportunities for multi-purpose tree legumes. proceedings of workshop, Bogor, Indonesia. ACIAR Proceedings No. 57. Australian Centre for International Agricultural Research,Canberra, Australia, pp. $35-38$.

Tantengco, O. A. G., \& Jacinto, S. D. (2015). Cytotoxic activity of crude extracts and fractions from Premna odorata (Blanco),Artocarpus camansi (Blanco) and
Gliricidia sepium (Jacq.) against selected human cancer cell lines. Asian Pacific Journal of Tropical Biomedicine, 5(12), 1037-1041.

Tandon, P., Kumaria, S., \& Das, M. C. (2012). Plant resources of India: Potentials for future development. Proceedings of the National Academy of Sciences, India, 82(S2), 283-289.

Thitiprasert, W., Ratanasatien, C., Chitrakon, S., Watanesk, O., Chotechuen, S., SinsawatForrer, V., Sommut, W., Somsri, S., Samitaman, P., \& Changtragoon, S. (2007). Country report on the state of plant genetic resources for food and agricultural in Thailand. FAO/government cooperative program. Bangkok. Thailand. 137 pp.

Troeh, F. R., \& Thompson, L. M. (2005). Soils and soil fertility ( $6^{\text {th }}$ ed.). Iowa, USA: Blackwell Publishing Professional. 489 pp.

Villegas-Pangga, G. (2010). KAKAWATE (Gliricidia sepium, leguminosae) as a soil amendment and biological control of soil-borne pathogens; The Philippines experience. Acta Horticulturae, 883, 309315.

Woodruff, D. S. (2010). Biogeography and conservation in Southeast Asia: How 2.7 million years of repeated environmental fluctuations affect today's patterns and the future of the remaining refugial-phase biodiversity. Biodivers Conserv, 19, 919 $-941$. 